\title{
English as a Lingua Franca: Applied Linguistics, Marxism, and Post-Marxist theory ${ }^{1}$
}

\section{Inglês como Língua Franca: Linguística Aplicada, marxismo e a teoria pós-marxista}

John Robert Schmitz*

Universidade Estadual de Campinas (UNICAMP)

Campinas - São Paulo / Brasil

Post-Marxism is born of disillusion, although it can express optimism about a political future free from the constraints of Marxist orthodoxy.

(Sim, 2000, p. 3)

\begin{abstract}
This paper is motived by a reading of "English as a Lingua Franca: An Immanent Critique" (O'REGAN, 2014), who claims that ELF researchers place their work at the forefront of debates with regard to what function and form English should play in the lives of its numerous speakers worldwide. O'Regan questions the use of an epistemology based on a positivist and objectivist paradigm, connected to a postmodernist and poststructuralist 'sensibility'. To attempt a fair analysis of O'Regan's critique of ELF, I consider it essential to examine Marxist theory in the light of the analyses of Sim's (2000) Post-Marxism and of the work published by Laclau and Mouffe (1985). My reading leads me to claim that traditional Marxist thinking is compromised by its association with authoritarian and totalitarian stances, as opposed to Post-Marxist views of pluralism, libertarianism, and openness to the cultural climate of postmodernism. Based on the disillusions of post-Marxist thinkers, I conclude that the views of classical Marxism are not applicable to 'English as a Lingua Franca'
\end{abstract}

KEYWORDS: truth; fetish; qualitative research; Frankfurt School; globalization; post-Marxism.

\footnotetext{
*john.schmitz@uol.com.br

${ }^{1}$ I want to thank the anonymous readers for their thorough and patient reading of this paper. The remaining faults are my responsibility. I appreciate the very painstaking revision of my paper by the proofreader.
} 


\begin{abstract}
RESUMO: A motivação deste artigo se deve a minha leitura do trabalho "English as a Lingua Franca: An Immanent Critique" (O’ REGAN, 2014) que afirma que os pesquisadores ligados a ELF situam- no centro de debate com respeito à função e à forma que a língua inglesa deve desempenhar por parte dos numerosos falantes no mundo inteiro. O' Regan questiona o uso de uma epistemologia baseada num paradigma positivista e objetivista atrelado a uma "receptividade" pós-modernista e pós-estruturalista. Com a finalidade de alinhavar uma análise ponderada da crítica a ELF elaborada por O’ Reagan, afirmo que é essencial examinar a teoria Marxista à luz da abordagem pósMarxista de SIM (2000) e à análise da obra de LACLAU e MOUFFE (1985). A leitura dessas fontes me leva a argumentar que a teoria clássica do marxismo é comprometida devido a sua ligação com posturas autoritárias e totalitárias em contraste com a visão pluralista, libertária e abertura ao clima cultural do pós-modernismo. Com base na desilusão dos pensadores pós-marxistas, concluo que as ideias do marxismo tradicional não são aplicáveis ao Inglês como Língua Franca.
\end{abstract}

PALAVRAS-CHAVE: verdade; fetiche; pesquisa qualitativa; Escola de Frankfurt; globalização; pós-marxismo.

\title{
1 Introduction
}

Sridhar (1990, p. 173), quite some time ago, considered the discipline of applied linguistics to be plural in nature ("What are applied Linguistics", my emphasis), for it is a diverse field concerned with "language in its total human and environmental context". In the light of his remarks, I consider that the word odyssey, with respect to applied linguistics, is appropriate, as the word entails a crossing, that is, a travessia (a word from the Portuguese language), indicating a transformation, a radical change, or a turn in the discipline since the 1970s. The discipline has indeed undergone "a long and eventful [...] journey or process" (cf. Concise Oxford English Dictionary, $11^{\text {th }}$ on-line edition). My objective here is not to provide a history of the field, as there are many publications that have provided accounts of the development of the area, including De Bot (2015), Grabe (2010), and Davies (2007). How applied linguists have positioned themselves with regard to conflicting views on different issues is a useful guide to know where we have been. In addition, it is important to attempt to discern where the discipline is going; indeed, the dramatic changes in the discipline's state of the art in recent years suggest a veritable reinvention of the endeavor: Applied Linguistics as a Social Science (SEALEY; CARTER, 2004) and Social Class in Applied Linguistics (BLOCK, 2014). Indeed the postmodern turn in applied linguistics that focuses on identity, stratification, social class, and linguistic 
and racial prejudice contribute to new understandings of the initial concern inherent within the discipline - the teaching and learning of languages. Pennycook (1994, p.141) refers to the "disciplining" of applied linguistics in the early 1960s, since English was constructed as an export commodity focused on the ideology of the native speaker and the political clout of the United Kingdom and the USA. McHENRY (2002), in her critical review of The Oxford Handbook of Applied Linguistics (KAPLAN, 2002), refers to "World Englishes", a research area that appeared in the mid-80s but that was not covered in the Handbook published in 2002. In the fourteen years or more that have passed, the literature dealing with post-colonial Englishes, or "World Englishes" (SCHNEIDER, 2003), has burgeoned to include "World English" (BRUTT-GRIFFLER, 2002), "lingua franca negotiations" (FIRTH, 1990) and "English as a Lingua Franca (ELF)" (JENKINS, 2007). Linked to the postmodern turn and poststructuralism, ELF, in its relatively short lifespan, has opened the door to both enthusiastic acceptance (SEIDLHOFER, 2001; COGO AND DEWEY, 2012) along with constructive criticism (FERGUSON, 2009; DAUER, 2005; HOUSE, 2003), and some uninformed rejection (PRODROMOU, 2008).

There has been resistance based on classroom concerns (DZIUBALSKA-KOLACZYK, 2005; KUO, 2006; PRODROMOU, 2008), which supports the inner circle "native speaker" L1 model. ELF functions as a contact language and provides an alternative to the teaching of the hegemonic varieties of English that have privileged and continue to privilege native speakers of the standard varieties (British English, General American English, etc.). Readers of ELF literature are indeed familiar with these criticisms; there is no need to repeat them here (FERGUSON, 2009; COGO; 2011).

A recent criticism of ELF, based on Marxist theory, is the paper published by John P. O’ REGAN, “English as a Lingua Franca: An Immanent Critique" (2014). Marxist thinking has been present in applied linguistics and can be observed in PENNYCOOK (1994, p. 50) and CANAGARAJAH (1999, p. 27, 28, 35). Holborow (1999) also published one of the first books on Marxism in the field of applied linguistics and more recently co-authored a critical text dealing with neoliberalism and global capitalism (BLOCK; GRAY; HOLBOROW, 2012).

At this point in my exposition, there is a need for an explanation of how I proceed with the analysis of the aforementioned article, that is, what 
I intend to do and what I will not attempt. In the case of the "immanent critique" (O'REGAN, 2014), the journal of Applied Linguistics invited researchers who are active in the field of "English as a Lingua Franca" to respond in the Forum section of the journal in the first issue of 2015. The debate proceeded with the article "ELF researchers take issue with 'English as a lingua franca: an immanent critique" (BAKER; JENKINS; BAIRD, 2015), followed in the same issue by H.G. Widdowson's (2015) response, "Contradiction and Conviction. A Response to O’Regan". The "Forum" section was concluded with O' Regan's (2015) rebuttal, "On AntiIntellectualism, Cultism, and One-Sided Thinking. O'Regan replies.”

The debate in the "Forum" section of Applied Linguistics entails three articles. It would not be a practical undertaking to attempt to comment on those papers owing to the polyphony of voices in the different presentations, particularly in that presented by Baker et al. (2015). I restrict myself here to attempt a personal, close reading of the initial paper that triggered the three subsequent papers in order to dialog directly and respectfully with O’Regan (2014).

\section{John P. O’Regan, “English as a Lingua Franca: An Immanent Critique"}

O'Regan's (2014) article presents a provocative intervention in the discipline of applied linguistics for Karl Marx (1818-1883), and Marxism may very well encounter fruitful dialog thanks to the work of scholars dealing with issues of social class, social stratification, and race (BLOCK, 2014). Here we are dealing with thorny problems that tend to hinder egalitarian access to employment, quality health care, housing, and education. Indeed Marxist thought, along with its different versions and interpretations, has historically been present in the Social Sciences. In fact, O'Regan presents a thought-provoking and challenging view of the ELF movement. In my reading of his paper, I encountered a number of problematic issues, which I will respectfully present in the remainder of this article.

\section{ELF: Transgressive or "ideologically conservative"?}

O'Regan (2014, p. 534) claims that ELF is "ideologically conservative". I perceive the movement rather as being transgressive, for it questions the legitimacy of an inner circle "native speaker" hegemony of English. As a 
contact language, ELF liberates prospective learners from being pressured to sound like language users from British, American or Australian varieties. ELF is democratic, as its advocates do not dictate, let alone suggest, that it should replace the inner circle varieties. It is the learners that must decide whether they prefer to learn a standard variety (British, American, Australian, etc.), outer circle varieties (Indian, Nigerian), or English as a Lingua Franca. It comes as a surprise that O'Regan does not question the presence of the EFL industry, indeed a part of "globalized capitalism." He claims that the notion of power as conceived by ELF is "something possessed by some NS speakers in their unjust domination of others (NNS)" (2014, p. 547). This statement simplifies the problem, for the real (my emphasis) domination and power stem from the use of English as a commodity exported particularly by the UK and the USA (British Council, USIS), international publishers, and different foundations. ELF also questions the ELT testing philosophy based on the norms of the correctness of inner circle Englishes in detriment of the norms of indigenized varieties in outer circle nations. O'REGAN appears to ignore the reality that NNS (so-called nonnative speakers) in many parts of the world have for some time been empowered and are able to resist linguistic imperialism in teaching English (CANAGARAJAH, 1999). According to Canagarajah, teachers in Sri Lanka resist pedagogical materials imported from the West; they appropriate them "to different degrees in terms of the needs and values of the local communities" (p. 123).

Brutt-Griffler (2002, p. 182) views her model of "World English" as instrumental in "decentering applied linguistics" from its long-term association with the center varieties of English and their respective cultures. Both Canagarajah (1999), in "The textbook and its hidden curriculum", and Pennycook (1994), in "International Textbooks", have pointed to the imposition of textbooks with their inappropriate methodology for countries in both the Kachruvian outer and expanding circles. ELF may very well be considered a way of "resisting linguistic imperialism" to echo the subtitle of Canagarajah (1999).

\section{Criticism of qualitative research}

O'Regan (2014, p. 537) censures ELF for “[...] its attachment to positivist and objectivist modes of research enquiry as bases for establishing truth." Here, a problem arises, for he refers to the celebrated vade-mecum of the social sciences, The Landscape of Qualitative Research, edited by Norman 
K. Denzin and Yvona S. Lincoln (2008). On consulting another publication (with a different title) by the two distinguished social scientists, namely The Sage Handbook of Qualitative Research (2005), I observed in the authors' preface a definition of what qualitative research does. Denzin and Lincoln claim:

The qualitative research community consists of groups of globally dispersed persons who are attempting a critical interpretative approach that will help them (and others) make sense of the terrifying conditions that define daily life in the first decade of this new century. (2005, p. xiv).

I find that the words "globally dispersed persons" and "critical interpretive approach" echo some of the work being carried out in the field of Qualitative Applied Linguistics and particularly in Critical Applied Linguistics. Denzin and Lincoln (2005, p. xiv) continue to describe the work of their discipline with these very telling words:

These individuals employ constructivist theory, feminist theory, queer theory, critical race theory and cultural studies models of interpretation. They locate themselves on the borders between post-positivism and poststructuralism.

My concern here is the fact that I fail to understand O'Regan's disqualification of an established research paradigm, given that scholars in the area of qualitative research have recently been carrying out research in areas of interest to applied linguists: feminist theory, queer theory, and critical race theory, to name a few. Needed here is an evaluation of the paradigm and not an unfounded criticism of an important research paradigm.

\section{What is truth?}

The word truth appears in four instances in the author's paper and merely functions as a slogan, with no definition or explanation. One example is sufficient: "its lack [= ELF] of theoretical engagement in questions of ideology, discourse, power, truth (my emphasis) and the nature of the real..." (O'REGAN, 2014, p.535). In my view, everything is ideological, including the traditional or foundational applied linguistics that has tended to avoid a political stance, claiming neutrality. The thrust of ELF consists of an alternative to the hegemonic discourse of "Standard Language Ideology" that accompanies the real world, replete with plurilithic forms: Post-Colonial 
Englishes or World Englishes (SCHNEIDER, 2003) and World English (BRUT'T-GRIFFLER, 2002).

Lorna Weir (2008, p. 368) bases her understanding of truth and truth regimes on the work of Foucault. The construction of truth is indeed complex, as she claims:

I take "truth regime" as a "general politics of truth" in the sense Foucault, ${ }^{2}$ (2000b:131; 1994a:158) first proposed: "Each society has its regime of truth, its 'general politics' of truth, that is, the types of discourse it accepts and makes function as true." Foucault sketched several criteria of truth regimes: techniques that separate true and false statements; how true and false are sanctioned; the status given those who speak that which is recognized as truth. The concept of truth formula introduces another level of abstraction into the concept of truth regime: how things are made to appear, how they come to be represented, and how the relation between things and words is formulated.

Skelton (1997) observes that in the field of medicine the notion of truth is dealt with in three ways. Truth can be conceived as being (i) provisional, (ii) partial in the sense of being incomplete, and (iii) contextualized. Skelton also cites the work of Latour and Woolgar (1986, p. 75), in their lucid Laboratory Life: The Construction of Scientific Facts (Princeton: Princeton University Press, 1986, p. 75) who distinguish three levels of truth, namely (i) common knowledge or "facts-taken for granted", (ii) conjectures, and (iii) statements that need support by argumentation. Butler (2002, p. 116) contends that postmodernists "blur the differences between truth and fancy" in their pessimism with regard to the "inevitability of class or psychological conflict." Based on the work of Weir, Skelton, Latour and Woolgar, and Butler, I consider O’Regan's many references to truth to be underdeveloped. Butler (2002), in my view, is correct in his contention that postmodernists tend to be skeptical about truth that "often deprives them of a proper concern for the activities of reason-giving and rational negotiation and for procedural justice" (p. 115).

\footnotetext{
${ }^{2}$ To help my readers locate these two papers by Foucault, I cite them here: FOUCAULT, M., Truth and power. In: RABINOW, P. (Org.). Essential Works of Foucault 1954-1984. v.3: New York: The New Press, 2000b. p. 111-133. Foucault, M. Entretien avec Michel Foucault. In: FAUBION, J.B. (Org.). Dits etécrits, 1954-1988. v.3. Paris: Gallimard, 1994a [1977]. p. 140-160.
} 


\section{$6 \mathrm{ELF}$ as a fetish?}

Another problem in my reading of O'Regan's paper (p. 535) is his reference to "lingua franca fetishism." Schmidt (2016, p.53) states that there are a number of meanings of the word fetish, namely "artificial", "false", and "magic." This writer refers to the work of Charles de Brosses (1709-1777), author of Culte des dieux fétiches (1760 Genebra: Cramer), who observed that so- called primitive peoples believed in the inherent power of the objects they worshipped. It is easy to perceive fetishes in the colonized while ignoring one's own cultural practices. It would seem to me that almost anything can become a fetish. Schmidt (2016, p. 50) points to the erotic (sexual) fetishistic attraction to "feet, latex, and the use of boots" in individuals or among partners. I find O'Regan's attribution of a fetish to all engaged in the ELF movement as an opinion, since we are not presented with interviews or case studies with those who interact with others in their non-native English. It would be essential to know how ELF participants feel about their English, either ELF or the attempt to acquire an inner circle variety. One could argue that the reverence for inner circle Englishes and their respective native speaker guardians of "real" English might also viewed be as a fetish, or more likely as a bonanza, given there are those who indeed benefit from its power - (i) international publishers; (ii) university TESOL programs that market standard British or American English for their own financial gain; and (iii) government controlled language institutes and their agencies where we encounter "a hidden sales element in every English teacher, book, magazine, film-strip, and television programme sent overseas." (PENNYCOOK 1994, p.149). In his study of an alternative to classical Marxist theory, $\operatorname{Sim}^{3}$ (2000, p. 7) observes that Marxism "has made almost as much of a fetish out of work as capitalism has."

\section{Who are the speakers of ELF?}

We are told that speakers of English "[...] - of whatever stripe - in multicultural settings become users or speakers of an hypostatized O’Regan's emphasis) 'ELF'.' (O’REGAN, 2014, p. 536). The author's

\footnotetext{
${ }^{3}$ Stuart Sim, the author of Post-Marxism: An Intellectual History, is a member of the School of Arts \& Social Science at Northumbrian University. He has carried out extensive research in the fields of globalization, postmodernism, critical and cultural theories, and poststructuralism.
} 
words - "of whatever stripe" - are problematic, as this would include all (my emphasis) speakers, and in the myriad of multilingual events that occur in the world today, speakers of nativized varieties (Indian, Nigerian, and Singaporean speakers of English), inner circle speakers (L1s), as well as second language users from the expanding circle, may all be present. AILA Conferences are a good example of the pluricentricity of the language, where all "stripes" may be present. O'Regan (2014, p.540) characterizes the users of ELF as being "free of [...] gender and race." He considers those users to be "a narrow range of bilingual elites"; he adds that they "constitute an unrepresentative minority of English language practitioners globally, most of whom have been introduced to English as a required subject at school whether they liked it or not and regardless of their possible prospects of use; very few of these 'learners' actually make the transition to become users." My question with regard to this negative view is that it is based on the ideas of the authors he cites. O' Regan, I would contend, has not undertaken his own data analysis of the socio-economic origins of the ELF participants, no doubt due to his aversion to empirical studies.

\section{Which arrived on the scene first? ELF or postmodernism?}

The core problem here is that O'Regan (2014, p. 536) contends that the proponents of ELF wish (or will) the movement into existence on the basis of their reifying and metamorphosizing ELF, thereby transforming it into "a thing-in-itself." The author contends that ELF researchers resort simply to a linguistic structure, that is, the noun phrase "this special issue is written in ELF" and "this article took place in ELF" to project it rather magically into "material existence." When English replaced French in continental Europe, people slowly began to observe it as a form of leaner English (L2) and informally noted a certain commonality in the oral production of its many users. From this "abstraction", research projects began. The Vienna Voice recordings of ELF language practices and the text Analyzing English as a Lingua Franca: a Corpus-driven Investigation (COGO; DEWEY, 2012) are indeed "things-in-themselves" brought about by both flesh and blood agents, and active participants and researchers. We are not dealing with abstractions. O'Regan (2014, p.535) frequently refers to what he calls "transformationalist, postmodern, and poststructuralist sensibilities" that the ELF movement appropriates. He informs us early on in his paper that ELF "as a school of thought" has developed over "the past 15 years 
or so" (2014, p. 533). Indeed ELF's situatedness is relatively new, but the notions of postmodernism and poststructuralist predate it for quite some time and were in place even before ELF was conceived. The founders and proponents did not "appropriate" those notions, since they had no choice and since ELF was an outcome of the growth and dissemination of English worldwide. ELF is a product of both postmodernism and poststructuralism. Marxist theory is, in my view, an overarching socio-economic theory with a Political agenda (with a capital P) based on a platform envisaging a government of and by the proletariat. ELF is political (with a lower case letter p), given that it serves as a challenge to Standard Language Ideology.

\section{Marxism, Capitalism, Neoliberalism, and Globalization}

O'REGAN (2014, p. 540) is correct in stating that the advocates of ELF did not "critique or even name capitalism and its contemporary manifestation neoliberalism." It would appear that O'Regan wants ELF researchers, first of all, to understand and critique capitalism and neoliberalism, embrace Marxism, and then become Marxists and anticapitalists, indeed a gargantuan task! The difficulty with this view is that both worldly practices, Marxism and capitalism are not monolithic, since there are different types of capitalism (state capitalism, crony capitalism, regulatory capitalism, entrepreneurial capitalism) (ALIGICA; TARKO, 2015). Marxism is far from being a monolithic theory as well. Derrida, interviewed in 1980 by Easthope (1991, p. 239), states that "Marxism, of course, is not an entity. There is no one marxism (sic), there is not one marxist practice [...]." O'Regan presents us with a classical view of Marxism that fails to indicate that the theory has changed since the $19^{\text {th }}$ Century.

With regard to both neoliberalism and globalization, O'Regan tends to present a one-sided view regarding both phenomena. First of all, $\mathrm{O}^{\prime}$ ' Regan (p. 540) argues that ELF is "neoliberal bound" and beholden to "globalized neoliberal capitalism” (p.535). Hebron and Stack (2011) look thoroughly at the literature of globalization and neoliberalism. In an innovative format, the two authors disagree with one another. Hebron (2011, p. 51-52) argues that "Globalization promotes development", while Stack (2011, p.52) contends that "Globalization destabilizes economies." Undoubtedly, each author has their own biases, but readers are exposed to both favorable and unfavorable arguments in their texts. Here lies the merit of their book. They conclude with the following words: "[T] hroughout this book, we have illustrated 
how globalization as a concept, process, value system, and an end is neither black nor white, good nor bad." (HEBRON; STACK, 2011, p. 59). This view is radically different from that of Holborow (2007, p.16, accessed October 2016), who presents a view of neoliberalism that O'Regan would agree with, especially since he himself criticizes ELF for not dealing with neoliberalism while failing to point out his objections to what neoliberalism entails. Holborow (2007, p.16) makes an important point:

The interconnections between ideology and language are important beyond the context of education and TESOL. In the neo-liberal world in which we live, crass marketization and militarism has attempted to compel its logic on us all. Challenging the dominant neo-liberal consensus - its language, in educational practice, its ideological assumptions - is part of challenging the global order whose market fundamentalism and military exploits so many of us oppose (Retrieved, October 2016).

In my interpretation of the author's remarks, she is referring to inner circle standard varieties of English and not ELF, which I consider as way of de-hegemonizing English (PARAKRAMA, 1995, p. xii).

\section{Globalization: a negative or positive force in the $21^{\text {st }}$ century world?}

The sociologist Mauro Guillén (2001, p.235) asks if globalization is "civilizing, destructive, or feeble" and presents a critique of five main debates in the literature of social science. The merit of the paper is that the author provides data (GUILLÉN, p. 242), with names of authors and dates of their published articles (primary sources) who argue "yes" or "no" to five pertinent questions: (i) is globalization really happening?; (ii) does it produce convergence?; (iii) does it undermine the authority of nation-states?; (iv) is globality different from modernity?; and (v) is a global culture in the making? Globalization is complex and there is really no right or wrong answer to the queries. No author is looking for an ultimate truth, only possibly provisional one(s) (Skelton, 1997).

Guillén (2001, p.256) concludes with the following thought: "We need to engage in comparative work in the dual sense of using multiple methods of data collection and analysis, and of applying our theoretical and empirical tools to a variety of research settings at various levels of analysis". O'Regan (2014) might also reject the "theoretical and empirical tools" of sociology 
in the light of his criticism of "positivistic and objectivist epistemology" (p. 547), as well as his dismissal without a discussion of positivist and objectivist modes of research enquiry" (p. 537). There is also another dimension to the phenomena of globalization. Guillén (p. 237) argues that the phenomena began "with the dawn of history." In my view, globalization was truly in place with the colonization of the Americas by European powers and the subsequent meeting and miscegenation of the colonized, the enslaved, and the colonizers. The Spanish and Portuguese were early participants in the process of globalization, before the spread of English around the world.

O’Regan (2014, p.543) remarks that ELF proponents"present a view of globalization that has brought about fluidity and hybridity in language and where in global communication flows everybody is accommodating to everybody else to a playful postmodern manner". Indeed the adjective playful applies to postmodernism, particularly in art, music and literature. Yet other adjectives are part of postmodernists' stances: skeptical, critical, selfconsciousness, relativist, reflexive, and anarchic (BUTLER, 2002). O'Regan refers to postmodernism in many instances but fails to interact with it.

I argue that the phenomenon of globalization does not occasion "fluidity and hybridity" in all languages. It rather depends on territorial dissemination and the number of speakers. One might conjecture that Bulgarian or Albanian are probably less fluid and hybrid than Spanish or Arabic due to the territorial diffusion of the latter pair of languages in the world, as well as the large number of L1 speakers and L2 bilingual speakers.

My disagreement with O'Regan's critique of ELF is not based directly on reservations with regard to Marxism. We are all familiar with the violent struggles with labor and management in the course of the $19^{\text {th }}$ and $20^{\text {th }}$ centuries. Slavery is still prevalent in many parts of the world today. The horrors of child labor have not disappeared. Neither Marxism nor capitalism has solved the problems of social, economic, racial, and gender-based inequality in the world. Once again, my reaction to O'Regan is based on his failure to provide a more nuanced and "open" consideration of (i) Marxism, (ii) capitalism, (iii) neoliberalism, and (iv) globalization. Consequently, his views motivated me to read more about Marxist theory. 


\section{Marxism and its historical development}

My reading of O'Regan (2014) has led me to look more closely and critically at the vast literature dealing with Marxist theory or theories. A reading of Post-Marxism: an Intellectual History by Stuart Sim (2000) has provided me with an opportunity to delve deeper into both Marxism and capitalism. Sim's thoughts confirmed some of those thoughts lurking in my mind prior to contact with O' Regan's paper. In my own case, I have lived a good part of my life in the $20^{\text {th }}$ century; have seen the end of World War II, the collapse of Germany, the tragic bombardment of two Japanese cities, the Cold War, the destruction of the Berlin Wall and the end of the Soviet Union, and the 2003 invasion of Iraq. Based on these life experiences, what disturbed me while reading O'Regan's paper is his silence about the "totalizing imperative that is a defining characteristic of Marxism" (SIM, 2000 , p. 4). This author attempts to "rescue aspects of Marxist thought from the collapse of Marxism as a global cultural and political force" in the world today, and in his words with practices of "authoritarianism and totalitarianism at odds with the current commitment (theoretical as well as political) to cultural pluralism and libertarianism" (p. 1). In the second sentence of his introduction, Sim (p.1) cites the work of Ernesto Laclau and Chantal Mouffe, Hegemony and Social Strategy: Towards a Radical Democratic Politics (1985), ${ }^{4}$ who actually carry out the rescuing of Marxist thought due to the changing cultural climate at that time of writing. Sim credits Laclau and Mouffe for having crystallized Post-Marxist theory and for having argued for its development in the light of the presence of "poststructuralism, postmodernism, and second-wave feminism[...]"5 (SIM, 2000, p.1). With respect to the concept of postmodernism that O’ Regan repeatedly refers to but fails to engage with, I subscribe to Sim who considers postmodernist theory to be skeptical of grand narratives, such as Marxism; this "suspicion of grand narrative, or universal theory"

\footnotetext{
${ }^{4}$ Ernesto Laclau (1935-2014) was a professor of Political Theory at the University of Essex. His work entails the study of identity and discourse, and draws on post-structuralist theory. Chantal Mouffe works in the field of international relations and politics. She co-authored the text with Laclau, espousing a post-Marxist view of Marxist theory.

${ }^{5}$ The first-wave feminism examined the issue of suffrage and attempted to question obstacles to gender equality, specifically voting and property rights. Second-wave feminism cited by Sim (2000) widened the movement to include issues of sexuality, family, reproductive rights, and workplace equality.
} 
has motivated his post-Marxist (Sim's emphasis) stance. (SIM, 2000, p. 104). The author also points to the tension between traditional Marxist thought and postmodernism, since the objectives of the former are irreconcilable with those of the latter (SIM, 2000, p. 125).

For Sim, the text by Laclau and Mouffe is deemed to be so basic for an understanding of Post-Marxist thought that he devotes two chapters to analyze their contribution, namely Chapter 2 ("An Intellectual Malady? The Laclau-Mouffe Affair (I)" and Chapter 3 ("Without apologies: The LaclauMouffe Affair (II)"). Indeed Sim's book contains a book in a book. It comes as a surprise that O'Regan (2014, p. 546, 551) cites Laclau and Mouffe, but he does not inform his readers about the authors' disenchantment with traditional Marxist theory (O'REGAN, 2014 p. 1-3) or provide a critique of that theory in a "post-world". Had O'Regan not inadvertently omitted in his bibliography the sub-title of Laclau and Mouffe's text, "Towards a Radical Democratic Politics", he might have invested less in classical Marxist theory.

Sim (2000) identifies himself as a socialist and is by no means an exMarxist, let alone an anti-Marxist. O'Regan's view of the Frankfurst School appears to be limited, as he does not point to the conflicting voices within that intellectual movement. Sim (2000, p.1) points to the "dissenting voices", including Rosa Luxemburg, Ernesto Laclau, and Chantal Mouffe. In Sim's (2000) "intellectual history" of Post-Marxism, readers can accompany his search for "post-Marxist tendencies with the work of such theorists as Lukács, Luxemburg and the Frankfurt School, Bloch, Sartre, and, somewhat unwittingly perhaps, Althusser." (p. 80). In fact, this school of thought "carried on the campaign for a self-critical Marxism right up to, and arguably well beyond, the boundary with post-Marxism." (p. 80). While Sim advocates a critical stance on the part of Post-Marxism's stance toward postmodernism that "should not be conflated with the postmodernist cause" (p. 3), he agrees with Laclau and Mouffe, who argue for "a synthesis of Marxist, poststructuralist, and postmodernist thought" (p.12). At least these notions, particularly poststructuralism and postmodernism, are duly engaged by Sim, Laclau, and Mouffe. Callinicos (1989, p.8) argues that "classical Marxism is still capable of providing theoretical and political guidance through the contemporary world" and rejects postmodern thinking. What is lacking in O'Regan's critique of ELF is a deeper view of Marxism and its different interpretations, particularly when many of his prospective readers are English (from all parts of the world) teachers, and not all are familiar with the 
"sins" of capitalist exploitation described in Charles Dickens' novel, Hard Times (1854) [1954], set in the industrial city of Coketown, England. Younger teachers and students may be unfamiliar with the history of Marxist thinking.

\section{Summing up: The English as a Lingua Franca Movement}

The English as Lingua Franca movement deals with people who are content not to speak like native speakers of standard or prestige varieties. I argue that by subscribing to ELF, the speakers acquire "power over their own lives", a practice inimical to classical Marxism or "old-style communism" (SIM 2000, p. 8). ELF speakers do not have to sound like standard American speakers from the mid-West, nor do they have to obey lexical, syntactic, and pragmatic norms of other inner circle Englishes. In ELF interactions, the different participants do not correct one another, and if they fail to communicate, they simply "let it pass" and try to search for ways of negotiating meaning (FIRTH, 1996).

"Applying" Marxist thinking to a pedagogical project leads to an unfair comparison of a grand narrative, that is, classical Marxism compared with ELF, a "minor" discourse, relevant indeed to speakers of English particularly in the expanding circle. ELF is a human entity, whereas the celebrated thinker Karl Marx, according to Sim (2000, p. 56) needs to be humanized. Sim remarks that it is necessary to resist Marx's writings as a "rational totality" and goes on to argue that as a discourse it "can be raided for insights as how we should confront capitalism now (author's emphasis) bearing in mind that capitalism is different "and no longer conforms to Marx's analysis of it." Sim's humanization of Marx is well-motivated in the light of the many changes in the world since the $19^{\text {th }}$ Century.

Marx shifts from being holy writ to a point of departure for socialist thought. Neither should we feel under any obligation to reconcile the inconsistencies we find in Marx; that would be to adopt a quasitheological attitude to his work. This is Marx humanized, a Marx who does not know all the answers, who sometimes follows up wrong leads, draws faulty conclusions, and does not always provide arguments to support his assertions The semi-deified Marx of the Soviet and classical traditions vanishes. (SIM, 2000, p. 63).

O’ Regan's 'application' of Marxist thought to 'English as a Lingua Franca' ignores a discussion of the "unresolved conceptual issues in 
researching English as a Lingua Franca (ELF)" (FERGUSON, 2009, p. 117) that face the discipline of applied linguists in their work today. The issues cited by Ferguson are, for me, more pertinent to practicing language teachers, methodologists, and general and applied linguists than criticisms aimed at ELF based on a theory that has outlived its usefulness, taking into consideration the critical analysis of Marxism put forth by Sim (2000) and by Laclau and Mouffe (1985). O'Regan's “immanent critique” does not, in my view, lead to the end of ELF as an important research paradigm or to the termination of this community of practice. To be fair to O'Regan, I do not deny his right to be a stalwart traditional Marxist, just as Sim, Laclau, and Mouffe have the right to their post-Marxist stances. Indeed, we are dealing with conflicting discourses. Sim's Post-Marxist stance, it would appear, with its concern about views of pluralism, libertarianism, and openness in society may not coincide with Holborow's (1999) "Marxist view of language", to cite the subtitle of her book. The fact is that Marxist thinking is indeed present in applied linguistics today. In the realm of knowledge, there exist conflicting discourses. What is essential is an open-mindedness to differences and assertions, which, in Butler's (2002, p.115) words, must be supported "by verifiable evidence."

Ferguson presents a balanced analysis of ELF, pointing to positive points while indicating problems that need to be tackled. He argues that the interesting "recurrent, documented features of ELF, as they occur in spoken interaction, [are] anything other than communicatively effective variants." (FERGUSON, 2009, p.130). Important for students, parents, and teachers to understand ELF is the fact that the oral production of its community of speakers consists of an "expansion in repertoire" and not a conglomerate of errors or non-standard forms (FERGUSON, 2009, p.130). ELF is indeed a reality and has contributed to moving language teaching into the 'real word", replete with language variation in the outer circle, with supposed non-standard variants in the expanding circle, and far more variation in the inner circle than is officially admitted.

In closing this reflection, I would like to state that my reading of PostMarxism. An Intellectual History by Stuart Sim (2000) has contributed to my understanding of Marxism from a different light, that is, from the viewpoint of Post-Marxist thinking. Reading in this area of Post-Marxist studies has enabled me to confirm some of my reservations with the excesses of Marxism during the Stalinist period. My work here kindled an interest in 
Marxism and Western Literature, as well as Post-Colonial literature, themes of interest for all those who work in the area of World English and Applied Linguistics. Marxist thinking will not disappear.

In a possible 'post-world', I am attracted to Mouffe's view "that the existence of every identity is the affirmation of a difference" (apud SIM, 2000 , p. 45). A world where one encounters a stance of 'agonistic pluralism' that does not view an opponent as an enemy "to be destroyed, but as an adversary that must be tolerated" (apud SIM, 2000, p. 45) is a place that I would feel at ease. With regard to the notion "democracy", which is often a cliché or a buzz word, I laud the reference to "a pluralist-orientated radical democracy". Sim (2000, p. 27), throughout his exposition, warns that there is a danger of falling into both essentialism and utopian positions. This is always the risk in any academic endeavor. A reward for me as a reader is that the author provides a painstaking and critical review of many conflicting points of view, indeed an "intellectual history".

\section{References}

ALIGICA, P.D.; TARKO, V. Capitalist Alternatives: Models, Taxonomies and Scenarios. Abingdon: Routledge, 2015.

BAKER, W.; JENKINS; J.; BAIRD, R. ELF researchers take issue with 'English as a lingua franca: an immanent critique.' Applied Linguistics, Oxford, v. 36, issue 1, p. 121-123, 2015.

BLOCK, D.; GRAY, J.; HOLBOROW, M. Neoliberalism and Applied Linguistics. London: Routlege, 2012.

BLOCK, D. Social Class in Applied Linguistics. New York: Routledge. 2014.

BRUTT-GRIFFLER J. World English: A Study in its Development. Clevedon: Multilingual Matters, 2002.

BUTLER, C. Postmodernism: A Very Short Introduction. Oxford: Oxford University Press, 2002.

CALLINICOS, A. Against Postmodernism: A Marxist Critique. Cambridge: Polity Press/Blackwell , 1989.

CANAGARAJAH, A.D. Resisting Linguistic Imperialism in English Teaching. Oxford: Oxford University Press,1999.

COGO, A. English as a Lingua Franca: concepts, use, and implications. ELT Journal Oxford, v. 66, issue 1, p. 97-105, 2011. 
COGO, A; DEWEY, M. Analyzing English as a Lingua Franca: A Corpus-driven Investigation. New York: Continuum, 2012.

DAUER, R.M. The Lingua Franca Core: A New Model for Pronunciation Instruction. TESOL Quarterly, New York, v. 39, n. 3, p. 543-550, Sept. 2005.

DAVIES, A. History and Definition of Applied Linguistics. In: . $A n$ Introduction to Applied Linguistics. Edinburgh: Edinburgh University Press, 2007.

DE BOT, K. A History of Applied Linguistics from 1980 to the Present. London: Routledge, 2015.

DENZIN, N.; LINCOLN, Y. The Sage Handbook of Qualitative Research. $4^{\text {th }}$ ed. Thousand Oaks: Sage Publications, 2005.

DICKENS, C. Hard Times. London: Penguin Books, [1854], 1994.

DZIUBALSKA-KOLACZYK, K. Native or non-native? This is the question: which English to teach in the globalized world? In: PHONETICS TEACHING AND LEARNING CONFERENCE (PTLC), 2005, London. Proceedings... London, 2005. p. 1-4.

EASTHOPE, A. British Post-Structuralism. London: Routledge, 1991.

FERGUSON, G. Issues in researching English as a lingua franca: a conceptual enquiry. International Journal of Applied Linguistics, New York, v. 19, issue 2, p.117135,2009

FIRTH, A. 'Lingua Franca' negotiation: towards an international approach. World Englishes, New York, v. 9, issue 3, p. 269-280, 1990.

FIRTH, A. The discursive accomplishment of normativity: On 'lingua franca' English and conversation analysis. Journal of Pragmatics, London, v. 26, p. 237-259, 1996.

GRABE, W. Applied Linguistics!: A Twenty-First Century Discipline. In: KAPLAN, R. D. (Ed.). The Oxford Handbook of Applied Linguistics. $2^{\text {nd }} \mathrm{ed}$. Oxford: Oxford University Press, 2010.

GUILLÉN, C. Is Globalization Civilizing, Destructive, or Feeble? A Critique of Five Key Debates in the Social Science Literature. Annual Review of Sociology, Palo Alto, CA., v.27, p 235-260, 2001.

HEBRON, L.; STACK, J. Globalization: Debunking the Myths. $2^{\text {nd }}$ edition. Boston: Longman, 2011.

HOLBOROW, M. The Politics of English: A Marxist View of Language. London: Sage Publication Inc., 1999. 
HOLBOROW, M. Ideology and Language: The Interconnections between NeoLiberalism and English. Dublin: Dublin City University, 2007. Available at: < firgoa. usc.es/drupal/node/29985>. Retrieved on: October 17, 2016.

HOUSE, J. English as a Língua Franca: A Threat to Multilingualism. Journal of Sociolinguistics. New York, v. 7, issue 4, p. 556-578, 2003.

JENKINS, J. English as a Lingua Franca: Attitude and Identity. Oxford: Oxford University Press, 2007.

KAPLAN, R. (Ed.). The Oxford Handbook of Applied Linguistics. Oxford: Oxford University Press. 2000.

KUO, J-C. Addressing the issue of teaching English as a Lingua Franca. ELT Journal, Oxford, v. 60, issue 3, p. 219-222, 2006.

MAKONI, S.; PENNYCOOK, A. (Ed.). Disinventing and Reconstituing Languages. Clevedon: Multingual Matters, 2006.

McHENRY, T. Review of The Handbook of Applied Linguistics. Oxford University Press, 2002. Available at: <http://linguistlist.org/pubs/reviews/get-review. cfm?SubID=6355>. Accessed on: May 29, 2016.

O' REGAN, J.P. English as a Lingua Franca: An Immanent Critique. Applied Linguistics. Oxford, v. 35, issue 5, p. 533-552, 2014.

O'REGAN, J. P. On Anti-Intellectualism, Cultism, and One-Sided Thinking. O’ Regan Replies. Applied Linguistics, Oxford, v. 36, issue 1, p. 128-132, 2015.

PARAKRAMA, A. De-hegemonizing Language Standards: Learning from (Post) Colonial Englishes about 'English'. Houndmills, Basingstoke, Hampshire: Palgrave, 1995.

PENNYCOOK, A. The Cultural Politics of English as an International Language. London: Longman, 1994.

PRODROMOU, L. English as a Lingua Franca: A Corpus-based Analysis. London: Continuum, 2008.

SCHMIDT, O.F. Os Saltos, rendas e outros fetiches. Mente e cérebro, São Paulo, Editora Segmento, n. 276, p. 50-55, jan. 2016.

SCHNEIDER, E. E. The Dynamics of New Englishes: From Identity Construction to Dialect Birth. Language: Journal of the Linguistic Society of America, Washington, D.C., v. 79, n. 1, p. 233-281, 2003.

SEALEY, A.; CARTER, B. Applied Linguistics as a Social Science. Clevedon: Multilingual Matters Limited, 2004. 
SEIDLHOFER, B. Closing a conceptual gap: the case for the description of English as a lingua franca. International Journal of Applied Linguistics, New York, v. 11, issue 2, p. 133-158, 2001.

SIM, S. Post-Marxism. An Intellectual History. London: Routledge, 2000.

SKELTON, J. The Representation of Truth in Academic Medical Writing. Applied Linguistics, New York, v. 18, issue 2, p. 121-140, 1997.

SRIDHAR, S.N. What are applied linguists? Studies in the Linguistic Sciences, UrbanaChampaign, v. 20, n. 2, p. 165-176, 1990.

WEIR, L. The Concept of Truth Regime. Canadian Journal of Sociology, Edmonton, Alberta, v. 33, n. 2, p. 367-389, 2008.

WIDDOWSON, H. G. Contradiction and Conviction: A Reaction to O'Regan. Applied Linguistics, Oxford, v. 36, issue 1, p. 124-127, 2015.

Data de submissão: 11/07/2016. Data de aprovação: 12/09/2016. 